\title{
ACetolactate Synthase ACtivity in Euphorbia heterophylla Resistant to AlS- ANd Protox- Inhibiting Herbicides ${ }^{1}$
}

\author{
Atividade da Enzima Acetolactato Sintase em Euphorbia heterophylla com Resistência Múltipla \\ aos Herbicidas Inibidores da ALS e da Protox
}

\author{
XAVIER, E. ${ }^{2}$, OLIVEIRA, M.C. ${ }^{2}$, TREZZI, M.M. ${ }^{2}$, VIDAL, R.A. ${ }^{3}$, DIESEL, F. ${ }^{2}$, PAGNONCELLI, F.D. ${ }^{2}$, \\ and SCALCON, E. ${ }^{2}$
}

\begin{abstract}
The objective of this study was to determine the activity of the enzyme acetolactate synthase in biotypes of wild poinsettia (Euphorbia heterophylla) with multiple resistance to ALS- and Protox- inhibitors in the presence and absence of imazapyr, imazethapyr and nicosulfuron. We conducted in vitro assay of ALS enzyme extracted from plants of Vitorino, Bom Sucesso do Sul and Medianeira biotypes (with multiple resistance) and a susceptible population in the absence and presence of imazapyr, imazethapyr and nicosulfuron. In the absence of herbicides, biotypes with multiple resistance showed higher affinity for the substrate of the enzyme compared with the susceptible population. The herbicides imazapyr, imazethapyr and nicosulfuron had little effect on the enzyme activity of ALS-resistant biotypes and, conversely, high inhibitory effect on ALS of the susceptible population. Resistance factors were very high, greater than 438, 963 and 474 for Vitorino, Bom Sucesso do Sul and Medianeira biotypes, respectively. The resistance to ALS inhibitors is due to the insensitivity of ALS to herbicides of both imidazolinone and sulfonylurea groups, characterizing a crossresistance.
\end{abstract}

Keywords: cross resistance, wild poinsettia, mechanism of resistance.

RESUMO - O objetivo deste trabalho foi determinar a atividade da enzima ALS em biótipos de leiteiro (Euphorbia heterophylla) com resistência múltipla aos inibidores da ALS e da Protox na presença e ausência dos herbicidas imazapyr, imazethapyr e nicosulfuron. Efetuou-se ensaio in vitro da enzima acetolactato sintase (ALS) extraida de plantas dos biótipos Vitorino, Bom Sucesso do Sul e Medianeira (com resistência múltipla aos inibidores da ALS e da Protox) e de um biótipo suscetivel, na ausência e presença dos herbicidas imazapyr, imazethapyr e nicosulfuron. Na ausência dos herbicidas, os biótipos com resistência múltipla demonstraram maior afinidade da enzima pelo substrato piruvato em comparação ao biótipo suscetivel. Os herbicidas imazapyr, imazethapyr e nicosulfuron produziram reduzido efeito sobre a atividade da enzima $A L S$ dos biótipos resistentes e, ao contrário, elevado efeito inibitório sobre a ALS do biótipo suscetivel. Os fatores de resistência foram elevados, superiores a 438, 963 e 474 para os biótipos Vitorino, Bom Sucesso do Sul e Medianeira, respectivamente. A resistência observada deve-se à insensibilidade da enzima ALS aos herbicidas tanto do grupo das imidazolinonas quanto das sulfonilureias, caracterizando resistência cruzada.

Palavras-chave: resistência cruzada, leiteiro, mecanismo de resistência.

\section{INTRODUCTION}

Acetolactate synthase (ALS) inhibiting herbicides have gained popularity in the farming community and have gradually increased their use owing the high agronomic efficiency in the control of several species at low doses recommended, the low toxicity to

1 Recebido para publicação em 16.5.2013 e aprovado em 20.8.2013.

2 Universidade Tecnológica Federal do Paraná, Pato Branco-PR, Brasil; <elo231@hotmail.com>; ${ }^{3}$ Universidade Federal do Rio Grande do Sul, Porto Alegre-RS, Brasil. 
mammals and the selectivity to several crops (Monqueiro et al., 2000; Vidal \& Merotto Jr., 2001). Currently, they represent the mechanism with the greatest number of herbicides for use in the marketplace (Devine \& Shukla, 2000).

The ALS enzyme (EC 2.2.1.6), also known as acetohydroxy acid synthase (AHAS), works on the synthesis route of amino acids valine, leucine and isoleucine (Devine \& Shukla, 2000). For its catalytic activity, the ALS requires the cofactors thiamine pyrophosphate (TPP), flavin adenine dinucleotide (FAD) and a divalent metal ion $\mathrm{Mg}^{2+}$ or $\mathrm{Mn}^{2+}$ (Kim et al., 2003). It represents the action target of many herbicides, as those belonging to the chemical groups of imidazolinone, pyrimidyl benzoate, sulfonanilide and sulfonylurea (Roman et al., 2007). These herbicides bind strongly to the enzyme acetolactate synthase, blocking access to its active site (Pang et al., 2003), resulting in a non-competitive inhibition (Devine et al., 1993).

The almost exclusive use of herbicides on weed control has led to an increase in the number of cases of resistance, being currently recorded worldwide 396 resistant biotypes, belonging to 210 species, among them 123 dicots and 87 monocots (Heap, 2012). Around $32 \%$ of all cases of weed resistance to herbicides refer to resistance to ALS-inhibitors, constituting a mechanism with the highest number of registered cases.

Wild poinsettia (E. heterophylla) (EPHHL) is a weed that causes great concern for its high capacity and competitive ability with crops (Chemale \& Fleck, 1982). Currently in the world are registered four cases of EPHHL resistance to herbicides, two of them with resistance to ALS-inhibitors, of which one has simultaneous resistance to Protox inhibitors (Trezzi et al., 2005; Heap, 2012). In EPHHL biotypes with multiple resistance to ALS- and Protox-inhibitors, detected in Southwestern Paraná State, probably the resistance has occurred in a cascade system (Trezzi et al., 2005). That is, initially there was a high selection pressure caused by ALS inhibitors, and then by Protox inhibitors, which resulted in selecting resistance to both mechanisms of action, at distinct times, in the same population. However, these biotypes have not yet had their resistance mechanism fully explained.

The measure of the ALS activity of resistant and susceptible biotypes, in response to increasing levels of imazapyr and imazethapyr, evidences that the resistance of EPHHL biotype to ALS inhibiting herbicides is probably due solely to the insensitivity of ALS to these herbicides (Vargas, 2000). Studies on herbicide resistance performed in vitro with ALS (Vargas et al., 1999; Wright \& Penner, 1998) have been carried out with the extraction and purification of the enzyme. The use of easier and faster methodology for extracting and purifying the ALS may facilitate the its use to diagnose resistance to herbicide (Oliveira et al., 2002).

Thus the identification of resistance in weeds is an important tool for a better management, making more efficient the prevention and also improving the control of weeds already resistant. The rapid, effective and accurate diagnosis of resistance in a weed population helps preventing the spread of resistant seeds in the area, avoiding future problems (Vidal et al., 2006).

In this context, this study aimed to compare the activity of ALS of multiple resistant biotypes with susceptible biotype, in the absence and in the presence of enzyme inhibiting herbicides imazapyr, imazethapyr and nicosulfuron.

\section{MATERIAL AND METHODS}

The experiment used EPHHL biotypes susceptible (S) and suspected of multiple resistance (R) to ALS and Protox inhibitors. Biotypes used were called Bom Sucesso do Sul, Vitorino, Medianeira and Suscetivel, with origin in the municipalities of Bom Sucesso do Sul, Vitorino and Medianeira (Paraná State) and São Paulo (São Paulo State), respectively.

The first experimental step was held in greenhouse, where biotypes were sowed in pots, for collection of leaf tissue. This collection was performed when EPHHL plants reached the stage of three to four leaves. At the time of collection, plant material was identified, and immediately frozen in liquid nitrogen. 
The second step consisted of ALS enzyme assay in laboratory. This assay was based on the method put forth by Gerwick et al. (1993), with modifications. The enzyme extraction occurred with maceration of the EPHHL plant material, frozen in liquid nitrogen with $50 \mathrm{mM}$ potassium phosphate buffer, $\mathrm{pH} 7.6$ $(3: 1 \mathrm{v} / \mathrm{m})$, containing per $100 \mathrm{~mL}$ solution, $2.2 \mathrm{~g}$ sodium pyruvate $(200 \mathrm{mM}), 0.025 \mathrm{~g}$ magnesium chloride $(1.25 \mathrm{mM}), 0.057 \mathrm{~g}$ thiamine pyrophosphate (TPP) $(1.25 \mathrm{mM})$ and $0.207 \mathrm{~g}$ flavin adenine dinucleotide (FAD $2.5 \mu \mathrm{M}$ ). During the maceration was added polyvinylpolypyrrolidone (PVPP) at a ratio of $0.25 \mathrm{~g}$ per gram of plant material. The macerated material was filtered and centrifuged at $15,500 \mathrm{rpm}$ for 15 minutes at $4{ }^{\circ} \mathrm{C}$, obtaining thus the enzyme extract.

For the in vitro ALS assay in test tubes, it was added $500 \mu \mathrm{L}$ distilled water (for the positive control - 100\% ALS activity) or $500 \mu \mathrm{L}$ herbicide solution, adding $250 \mu \mathrm{L} 1.8 \mathrm{~N} \mathrm{H}_{2} \mathrm{SO}_{4}$ to the negative control ( $0 \%$ ALS activity). Later, was added $500 \mu \mathrm{L}$ enzyme extract to the tubes, which were incubated for $90 \mathrm{~min}$ at $37^{\circ} \mathrm{C}$. After this, reactions were stopped with $250 \mu \mathrm{L} 1.8 \mathrm{~N} \mathrm{H}_{2} \mathrm{SO}_{4}$, except for the negative control. All treatments consisted of three replicates.

Subsequentely, the second incubation has begun for $15 \mathrm{~min}$ at $60{ }^{\circ} \mathrm{C}$ to form acetoin, which occurs by the reaction of sulfuric acid with acetolactate formed during the first reaction. Then, it was added $700 \mu \mathrm{L} 2 \mathrm{~N}$ sodium hydroxide solution containing creatinine at $0.25 \%$ and naphthol at $2.5 \%$ for the formation of the colored complex. Thereafter, tubes were again incubated for $15 \mathrm{~min}$ at $60^{\circ} \mathrm{C}$. Absorbances were then measured with a spectrophotometer (Shimadzu UV-1800) at $535 \mathrm{~nm}$.

Aqueous solutions of imazethapyr, imazapyr and nicosulfuron were prepared for the ALS assay. Final concentrations of herbicides in test tubes were 0 (100\% enzyme activity), $0.5,1,2,4,6$ and $8 \mu \mathrm{M}$ for the $\mathrm{S}$ biotype and $0,500,1000,1500,2000$ and $3000 \mu \mathrm{M}$ for $\mathrm{R}$. For enzyme activity assays were used different concentrations of pyruvate $(0 ; 2.5 ; 5 ; 10 ; 15$; 20 ; 40; 60; 80; 100; $160 \mathrm{mM}$ for the biotype S; and $0 ; 2.5 ; 5 ; 10 ; 15 ; 20 ; 40 ; 60 \mathrm{mM}$ for R), following the same procedures described above.
In inhibition assay, results were calculated in percentage, considering as $100 \%$ activity (without inhibitor). Values of ALS activity were expressed in enzyme unit per $\mathrm{mg}\left(\mathrm{U} \mathrm{mg}^{-1}\right)$, in which one unit of acetolactate synthase is defined as the amount of enzyme able to produce 0.1 absorbance unit per minute, expressed according to the total protein concentration (specific activity). The protein content was determined by the Bradford method (1976).

Data were subjected to analysis of variance, by the $F$-test $(p<0.05)$. Mean values between treatments were compared by the least significant difference test (DMS) at 5\% probability. Regressions between dependent variables and herbicide concentrations were fitted using non-linear models, by employing the three parameter logistic model. Values obtained were used to calculate the $\mathrm{I}_{50}$, which represents the amount of inhibitor needed to inhibit 50\% enzyme activity, using the nonlinear regression logistic model (Seefeldt et al., 1995), as follows:

$$
y=a /\left(1+\left(x / x_{50}\right)^{b}\right)
$$

where: $\mathrm{y}=\operatorname{ALS}$ activity (\%); $\mathrm{a}=$ maximum asymptote; $\mathrm{x}=$ herbicide dose $(\mu \mathrm{M}) ; \mathrm{xI}_{50}=$ herbicide dose $(\mu \mathrm{M})$ corresponding to $50 \%$ inhibition of ALS enzyme and $b=$ slope of the curve.

Resistance factors (RF) were calculated through the ratio between the parameters $I_{50}$ of R biotypes by the $\mathrm{I}_{50}$ of the $\mathrm{S}$ biotype. For statistical analyses and graphs we used the softwares WINSTAT and Sigma-plot 11.0.

\section{RESULTS AND DISCUSSION}

The ALS activity presented a great variation between biotypes (Figure 1). The maximum velocity $\left(\mathrm{V}_{\max }\right)$ of ALS activity observed for $\mathrm{S}$ biotype was $026 \mathrm{U} \mathrm{mg}^{-1}$ with $160 \mathrm{mM}$ pyruvate. For biotypes Vitorino, Bom Sucesso do Sul, and Medianeira, it was obtained $0.45,0.49$ and $0.25 \mathrm{U} \mathrm{mg}^{-1}$, respectively, with the maximum concentration of $60 \mathrm{mM}$ pyruvate (Figure 1). Values of $\mathrm{K}_{\mathrm{M}}$ for biotypes $\mathrm{S}$, Vitorino, Bom Sucesso do Sul and Medianeira were, respectively, 33.7, 6.96, 16.9 and $4.1 \mathrm{mM}$ (Figure 1). In other words, the biotype $\mathrm{S}$ has lower affinity for the substrate than R biotypes. 

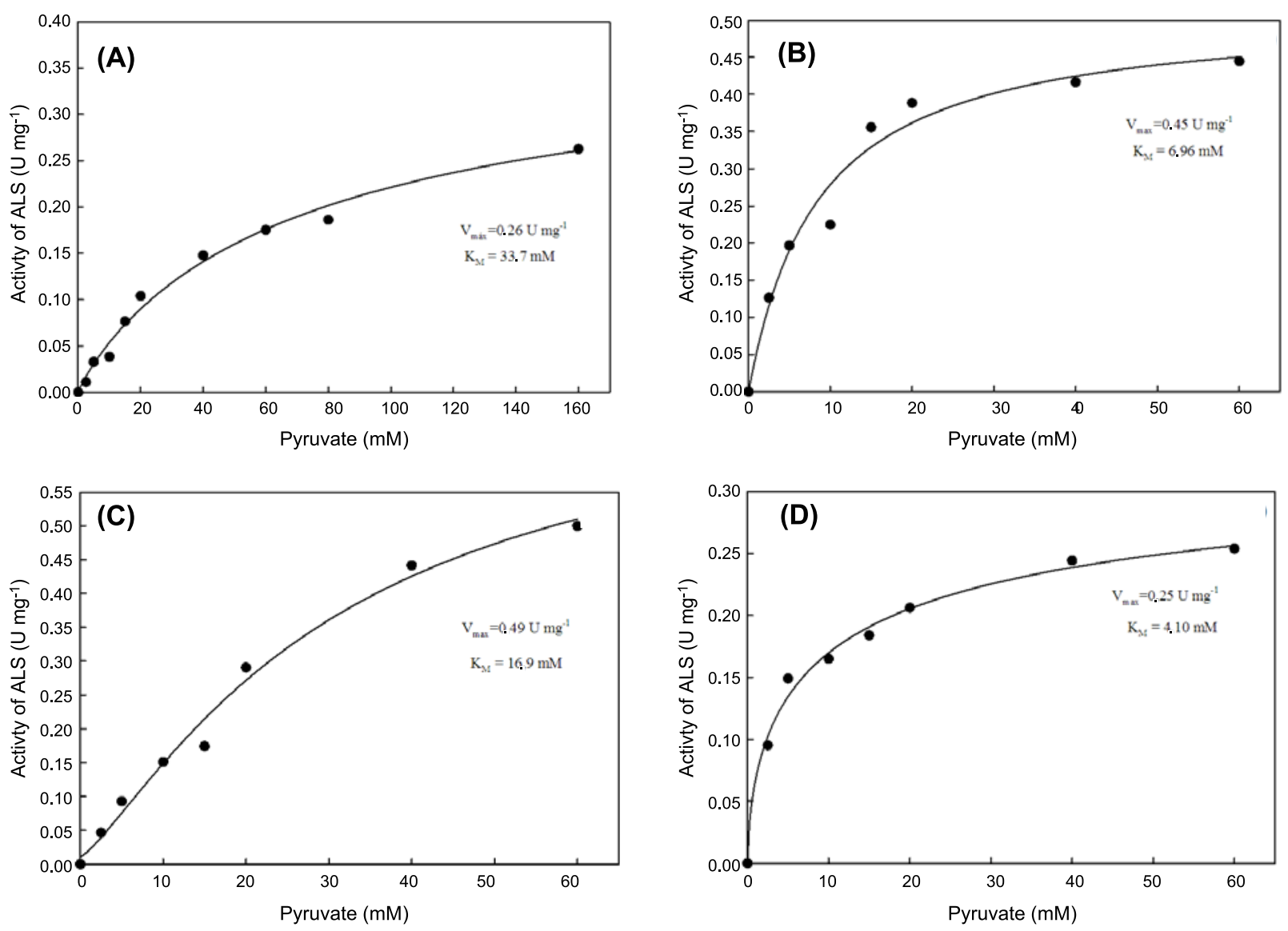

$\mathrm{K}_{\mathrm{M}}$ = concentration of pyruvate which provides half of the maximum speed of the reaction or the enzyme affinity for the substrate, and $\mathrm{V}_{\max }=$ maximum speed of the reaction.

Figure 1 - Activity of ALS enzyme of susceptible biotype (A) and resistant biotypes Vitorino (B), Bom Sucesso do Sul (C) and Medianeira (D) of E. heterophylla, for different concentrations of pyruvate.

Based on these results, it is hypothesized a possible mutation that may have led to change in the regulatory site, preventing or decreasing the binding of ALS inhibitors and providing resistance to herbicides in genotypes Vitorino, Bom Sucesso do Sul and Medianeira. The greater affinity of the ALS enzyme of $\mathrm{R}$ biotypes for the substrate can be related to the change in enzyme conformation, resulting from altered sequence of amino acids at the likely mutated site. Thus the efficiency of converting pyruvate was increased, since the $V_{\max }$ of the enzyme of $R$ biotypes were higher than of the enzyme of the S biotype. According to Dewaele et al. (1997), ALS herbicides can bind to the same site or different sites of the enzyme, since they are noncompetitive with the substrate.
Contrary to that observed in the present experiment, when analyzed the ALS activity of EPHHL biotype with resistance only to ALS inhibitors, Vargas (2000) registered values of $\mathrm{V}_{\max }$ of $0.28 \mathrm{U} \mathrm{mL}^{-1}$ for the $\mathrm{S}$ biotype and of $0.16 \mathrm{U} \mathrm{mL}^{-1}$ for the $\mathrm{R}$ biotype. The ALS enzyme of the $\mathrm{R}$ biotype presented $\mathrm{V}_{\max }$ lower than observed for the ALS of the S biotype, suggesting that the mutation in the gene encoding the ALS caused no significant change in enzyme affinity for the substrate (Vargas, 2000).

The ALS activity of the S biotype was greatly inhibited by all herbicides. With the highest concentration $(8 \mu \mathrm{M})$, the reduction in the ALS activity was $86 \%, 80 \%$ and $61 \%$, respectively for imazethapyr, imazapyr 
and nicosulfuron (Figure 2A). The use of the highest concentration of imazethapyr, imazapyr and nicosulfuron $(3,000 \mu \mathrm{M})$ resulted in reduced ALS activity of the R biotype Vitorino by 42,45 and $47 \%$, respectively (Figure $2 B$ ). For the biotype Bom Sucesso do Sul, the same concentration resulted in reduced enzyme activity in 31, 42 and 19\% (Figure 2C), for the same sequence of herbicides. The same concentration resulted in reduced ALS activity of the biotype Medianeira by $28 \%$ for imazethapyr, $71 \%$ for imazapyr and $42 \%$ for nicosulfuron (Figure 2D).

Considering the three herbicides, the average ALS inhibition of the S biotype was $75.6 \%$. A preliminary dose response test with the same concentration used in the S biotype $(8 \mu \mathrm{M})$ resulted in no enzyme inhibition of $\mathrm{R}$ biotypes (data not presented). The average enzyme inhibition considering all $\mathrm{R}$ biotypes and herbicides, employing the concentration of $3000 \mu \mathrm{M}, 375$ times higher than used for the $\mathrm{S}$ biotype, was only $41 \%$. This means that the ALS enzyme of R biotypes was much less inhibited by herbicides, which suggests a change in the inhibitor binding site of the protein (allosteric site), once the inhibition is noncompetitive (Vargas \& Roman, 2006), making it less sensitive to the herbicides (Figure 2).

In literature, there are several cases of mutations in ALS enzyme that originate the resistance to ALS inhibiting herbicides in weeds. Mutations at positions Ala 122, Pro-197, Trp-574 and Ser-653 of the ALS enzyme are found in biotypes of several resistant weed species, while mutations at other positions are less common (Tranel et al., 2012). For the
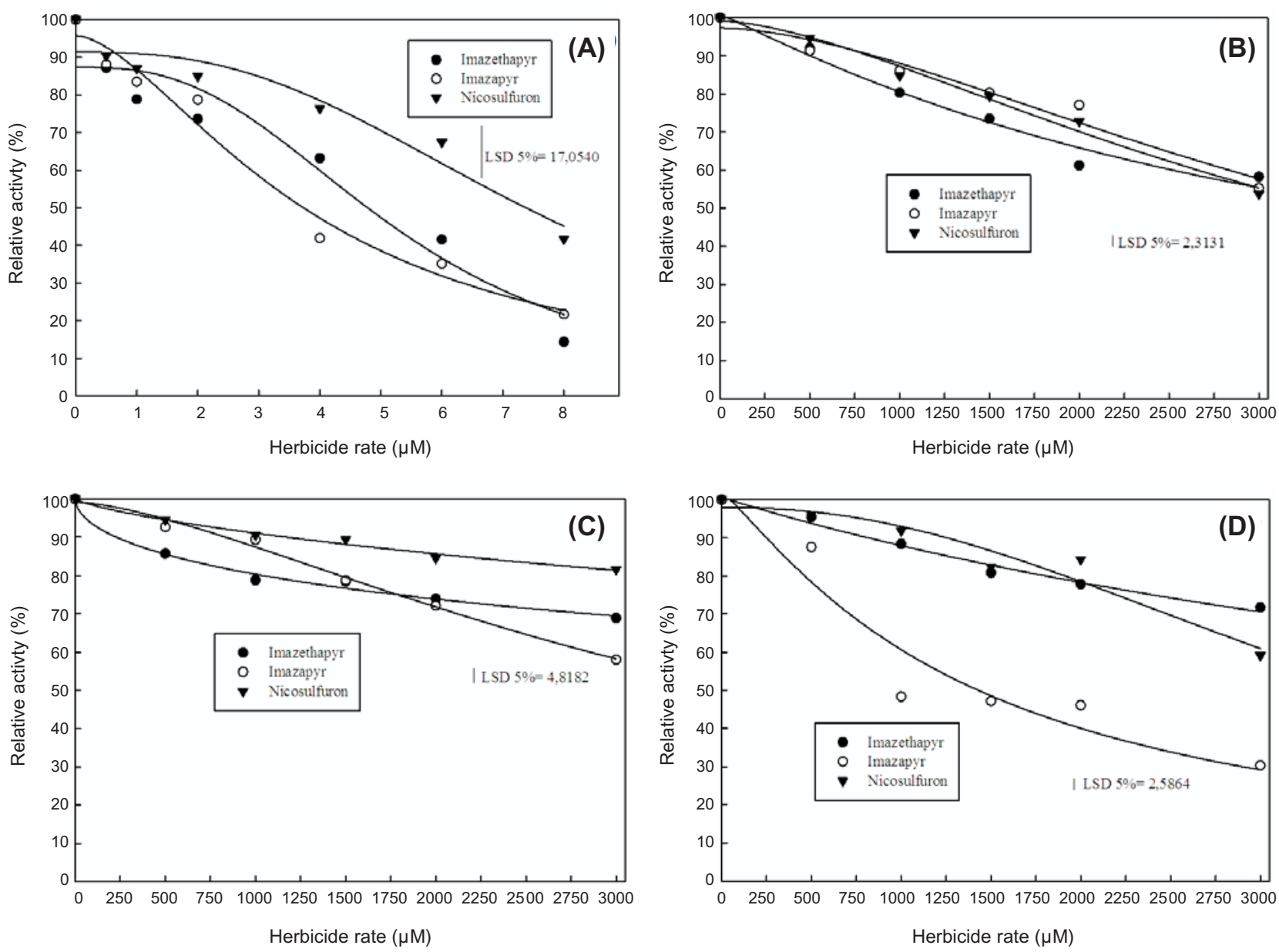

Figure 2 - Activity of ALS enzyme of susceptible biotype (A) and resistant biotypes Vitorino (B), Bom Sucesso do Sul (C) and Medianeira (D) of E. heterophylla, for different concentrations of the herbicides imazethapyr, imazapyr and nicosulfuron. 
imidazolinone group, there are replacement of Ala 122 (McNaughton et al., 2005; Riar et al., 2013), Ala 205 (Ashigh \& Tardif, 2007); Ser 653 (Patzoldt \& Tranel, 2001), Gli 654 (Laplante et al., 2009), and for the sulfonylureas, replacement at position Pro 197 (Yu et al., 2008); Asp 376 (Zheng et al., 2011); Arg 377 (Massa et al., 2011). The replacement of Trp574 causes high resistance to chemical groups of sulfonylureas and imidazolinones simultaneously (Patzoldt \& Tranel, 2002; Tan et al., 2007). The replacement of Ala-122-Tyr results in imidazolinone resistance, but not to sulfonylureas, while the replacement of Ala122-Tir originates imidazolinone resistance, sulfonylureas and sulfonanilide, probably because Tir present a residue much larger and more aromatic than the Thr (Han et al., 2012).

Biotypes presented great differences as for the concentration required to reduce $50 \%$ ALS activity $\left(\mathrm{I}_{50}\right)$ for herbicides (Table 1), which can be ascribed to intrinsic variations of ALS and differences in enzyme stability (Stidham \& Singh, 1991). Values of $I_{50}$ in the $S$ biotype were much lower (higher $\mathrm{I}_{50}=7.9 \mu \mathrm{M}$ ) compared with those obtained in Vitorino, Bom Sucesso do Sul and Medianeira (values of $\mathrm{I}_{50}>$ $1388 \mu \mathrm{M})$.

The highest RF observed for the biotype Vitorino was 953.8, for imazapyr. In the biotype Bom Sucesso do Sul was 2610.5, for imazethapyr. For the biotype Medianeira was 1344.8, for imazapyr. This shows the high resistance levels in these biotypes to ALS inhibiting herbicides tested herein. High resistance levels were detected for both sulfonylurea and imidazolinone groups, which characterize a cross-resistance.
Studies on ALS enzyme, extracted from $\mathrm{R}$ EPHHL plants, only ALS inhibitors evidenced $\mathrm{I}_{50}$ above $3000 \mu \mathrm{M}$ for imazapyr, and above $2000 \mu \mathrm{M}$ for imazethapyr, contrasting with values of $\mathrm{I}_{50}$ of $2 \mu \mathrm{M}$ for imazapyr and of $0.7 \mu \mathrm{M}$ for imazethapyr for S plants (Vargas, 2000), corroborating thus the values of the present study. Oliveira et al. (2002) verified $\mathrm{I}_{50}$ of 1961.0 and 13.8 in the assessment of ALS activity of $\mathrm{R}$ and S EPHHL biotypes, respectively, for imazaquin, and RF at 142. Much lower values of $I_{50}$ were registered in the assessment of ALS activity of C. difformis with the use of pyrazosulfuron-ethyl. The $\mathrm{I}_{50}$ for the $\mathrm{R}$ biotype was 73, whereas for the S biotype was 0.57 (Dal Magro et al., 2010). However, all results cited from studies performed in Brazil have proven the low activity of ALS of S biotypes, compared with $\mathrm{R}$ biotypes, in the presence of herbicides, pointing out the insensitivity of the enzyme as responsible for resistance.

In greenhouse with spraying of imazethapyr on intact plants of the Vitorino biotype (one of those evaluated herein), it was obtained RF of 15 (Trezzi et al., 2005). With biotypes of EPHHL R to ALS, Gelmini et al. (2001) found RF values for the control variable of 19 and 26, respectively for chlorimuron-ethyl and imazethapyr. RF values of the R biotype of B. pilosa were 40.92, 173.84, 57.47 and 57.16 for ALS inhibiting herbicides chlorimuronethyl, nicosulfuron, metsulfuron-methyl, and imazethapyr, respectively (Christoffoleti, 2002). In an experiment in greenhouse using $\mathrm{R}$ and $\mathrm{S}$ biotypes of $B$. pilosa, Christoffoleti et al. (1996) have determined $R F$ values at 370, 39, 26 and 12 for the R biotype, compared with the $\mathrm{S}$ biotype, respectively for imazethapyr, nicosulfuron, metsulfuron-methyl and chlorimuron-ethyl.

Table 1 - Imazethapyr, imazapyr e nicosulfuron rates needed to reduce by 50\% the activity of ALS enzyme of resistant and susceptible biotypes of E. heterophylla $\left(\mathrm{I}_{50}\right)$, and resistant factors (RF)

\begin{tabular}{|c|c|c|c|c|c|c|c|}
\hline \multirow{3}{*}{ Herbicides } & \multicolumn{4}{|c|}{$\mathrm{I}_{50} *$} & \multirow{2}{*}{\multicolumn{3}{|c|}{$\mathrm{RF}^{* *}$}} \\
\hline & \multicolumn{3}{|c|}{ Resistants } & \multirow[b]{2}{*}{ Susceptible } & & & \\
\hline & Vitorino & $\begin{array}{c}\text { Bom Sucesso } \\
\text { do Sul }\end{array}$ & Medianeira & & Vitorino & $\begin{array}{c}\text { Bom Sucesso } \\
\text { do Sul }\end{array}$ & Medianeira \\
\hline Imazethapyr & $3607.3^{1^{\prime \prime}}$ & $13888.1^{1 / /}$ & $7154.5^{\frac{1 /}{\prime}}$ & $5.3^{\frac{1 /}{}}$ & 678.0 & 2610.5 & 1344.8 \\
\hline Imazapyr & $3748.3^{\frac{1 /}{\prime}}$ & $3785.7^{1 /}$ & $1387.6^{-1 /}$ & $3.9^{1^{\prime}}$ & 953.8 & 963.3 & 353.1 \\
\hline Nicosulfuron & $3473.7^{1 /}$ & $20359.6^{1 /}$ & $3761.0^{\frac{1}{\prime}}$ & $7.9^{1^{\prime}}$ & 438.6 & 2570.7 & 474.9 \\
\hline
\end{tabular}

* Rates needed to reduce by $50 \%$ the activity (I50); ** RF $=$ I50 resistant / I50 susceptible. ${ }^{1 /}$ Logistic model with three parameters. 
$\mathrm{RF}$ values in laboratory experiments assessing the enzyme activity are mostly higher than obtained in experiments in greenhouse or in the field, for evaluation of control levels, because of working with purified material in which the enzyme is the evaluated factor, without interferences from other plant components. In experiments in greenhouse where herbicides are sprayed on intact plants, they have to overcome several barriers to reach the chloroplasts and the site of enzymatic action. This leads to higher values of $\mathrm{I}_{50}$ of the $\mathrm{S}$ biotype, and therefore lower RF values.

Cases of ALS resistance in EPHHL with high resistance factor prevent their control because the use of herbicides with this mechanism of action will not effectively control the target weed. The resistance by enzyme insensitivity, as in biotypes studied in the present work, ultimately results in higher resistance factor, being this resistance derived from a change in the primary structure of ALS, result from mutations (Devine \& Shukla, 2000).

The constant use of herbicides with the same mechanism of action leads to the emergence of $\mathrm{R}$ biotypes. The farming system currently used by farmers favors the appearance of $\mathrm{R}$ plants, but a management that combines rotation of mechanisms of action, with use of herbicides, following practices of an integrated management such as crop rotation and adoption of new methods for control, can result in more effective control of weeds and reduce temporarily the appearance of new cases of $\mathrm{R}$ weeds in the area.

Therefore, in the present study, the resistance of EPHHL biotypes with multi resistance to ALS inhibiting herbicides is ascribed to the lower sensitivity of this enzyme to these herbicides, possibly by altering its allosteric site, preventing or reducing the inhibitory activity. There was an increase of affinity of resistant biotypes for pyruvate, resulting from the resistance, which suggests that a change in primary structure (amino acid sequence) resulted in a more effective enzyme, in comparison with the $\mathrm{S}$ biotype, even in the absence of inhibitors. The loss of sensitivity of ALS in resistant biotypes occurs both in relation to the imidazolinone as the sulfonylureas groups, which characterizes a cross-resistance.

\section{LITERATURE CITED}

ASHIGH, J.; TARDIF, F. J. An Ala205Val substitution in acetohydroxyacid synthase of eastern black nightshade (Solanum ptychanthum) reduces sensitivity to herbicides and feedback inhibition. Weed Sci., v. 55, n. 6, p. 558-565, 2007.

BRADFORD, M. M. A rapid and sensitive method for the quantitation of microgram quantities of protein utilizing the principle of protein-dye binding. Anal. Biochem., v. 72, n. 1/ 2, p. 248-254, 1976.

CHEMALE, V. M.; FLECK, N. G. Avaliação de cultivares de soja (Glycine max (L.) em competição com Euphorbia heterophylla L. sob três densidades e dois períodos de ocorrência. Planta Daninha, v. 5, n. 1, p. 36-45, 1982.

CHRISTOFFOLETI, P. J. et al. Imidazolinone resistant B. pilosa biotypes in the Brazilian soybean areas. In: MEETING OF THE WEED SCIENCE SOCIETY OF AMERICA, 36., 1996, Norfolk. Abstract... Champaign: WSSA, 1996. p. 10.

CHRISTOFFOLETI, P. J. Curvas de dose-resposta de biótipos resistente e suscetível de Bidens pilosa L. aos herbicidas inibidores da ALS. Sci. Agric., v. 59, n. 3, p. 513-519, 2002.

DAL MAGRO, T. et al. Propriedades enzimáticas da enzima ALS de Cyperus difformis e mecanismo de resistência da espécie ao herbicida pyrazosulfuron-ethyl. Ci. Rural, v. 40, n. 12, p. 2439-2445, 2010.

DEVINE, M. et al. Physiology of herbicide action. Englewood Cliffs: Prentice Hall, 1993. 441 p.

DEVINE, M. D.; SHUKLA, A. Altered target sites as a mechanism of herbicide resistance. Crop Protec., v. 19, n. 8/ 10, p. 881-889, 2000.

DEWAELE, E. et al. Biochemical characterization of chlorsulfuron resistance in Cichorium intybus L. var. Witloof. J. Plant Physiol., v. 151, n. 1, p. 109-114, 1997.

GELMINI, G. A. et al. Resistência de biótipos de Euphorbia heterophylla L. aos herbicidas inibidores da enzima ALS utilizados na cultura de soja. Bragantia, v. 60, n. 2, p. 93-99, 2001.

GERWICK, B. C. et al. Rapid diagnosis of ALS/AHAS inhibitor herbicide resistant weeds. Weed Technol., v. 7, n. 2, p. 519-524, 1993.

Planta Daninha, Viçosa-MG, v. 31, n. 4, p. 867-874, 2013 
HAN, H. et al. A novel amino acid substitution Ala-122-Tyr in ALS confers high-level and broad resistance across ALSinhibiting herbicides. Pest. Manag. Sci., v. 68, n. 8, p. 1164-1170, 2012.

HEAP, I. International survey of herbicide-resistant weeds. 2012. Disponível em: <http://www.weedscience.org>. Acesso em: 24 jan. 2012.

KIM, S. et al. An active site arginine residue in tobacco acetolactate synthase. B. Korean Chem. Soc., v. 24, n. 12, p. 1799-1804, 2003.

LAPLANTE, J. et al. Multiple allelic forms of acetohydroxyacid synthase are responsible for herbicide resistance in Setaria viridis. Theor. Appl. Genet., v. 119, n. 4, p. 577-585, 2009.

MASSA, D. et al. Target-site resistance to ALS-inhibiting herbicides in Apera spica-venti populations is conferred by documented and previously unknown mutations. Weed Res., v. 51, n. 3, p. 294-303, 2011.

MCNAUGHTON, K. E. et al. Mutations in ALS confer herbicide resistance in redroot pigweed (Amaranthus retroflexus) and Powell amaranth (Amaranthus powellii). Weed Sci., v. 53, n. 1, p. 17-22, 2005.

MONQUEIRO, P. et al. Resistência de plantas daninhas aos herbicidas inibidores da ALS na cultura da soja (Glycine max). Planta Daninha, v. 18, n. 3, p. 419-425, 2000.

OLIVEIRA, M. F. et al. Atividade da acetolactato sintase de plantas de milho e de amendoim-bravo (Euphorbia heterophylla) resistentes e suscetíveis ao imazaquin. Planta Daninha, v. 20, n. 1, p. 77-82, 2002.

PATZOLDT, W. L.; TRANEL, P. J. ALS mutations conferring herbicide resistance in waterhemp. Proc. North Central Weed Sci. Soc., v. 56, n.1 p. 67, 2001.

PATZOLDT, W. L.; TRANEL, P. J. Molecular analysis of cloransulam resistance in a population of giant ragweed. Weed Sci., v. 50, n. 3, p. 299-305, 2002.

PANG, S. S. et al. Molecular basis of sulfonylurea herbicide inhibition of acetohydroxyacid synthase. J. Biol. Chem., v. 278, n. 9, p. 7639-7644, 2003.

RIAR, D. S. et al. Physiological and molecular basis of acetolactate synthase-inhibiting herbicide resistance in barnyardgrass (Echinochloa crus-galli). J. Agric. Food Chem., v. 61, n. 2, p. 278-289, 2013.

ROMAN, E. S. et al. Como funcionam os herbicidas: da biologia à aplicação. Passo Fundo: Berthier, 2007. 160 p.
SEEFELDT, S. S. et al. Log-logistic analysis of herbicide dose-response relationships. Weed Technol., v. 9, n. 2, p. 218-227, 1995.

STIDHAM, M. A.; SINGH, B. K. Imidazolinoneacetohydroxyacid synthase interactions. In: SHANER, D. L.; O'CONNOR, S. L. The imidazolinone herbicides. Boca Raton: CRC Press, 1991. p. 71-90.

TAN, M. K. et al. Molecular basis of multiple resistance to ACCase-inhibiting and ALS-inhibiting herbicides in Lolium rigidum. Weed Res., v. 47, n. 6, p. 534-541, 2007.

TRANEL, P. J.; WRIGHT, T. R.; HEAP, I. M. ALS Mutations from herbicide resistant weeds. Disponível em: <http://www.weedscience.com>. Acesso em: 27 jan. 2012.

TREZZI, M. M. et al. Multiple resistance of acetolactate synthase and protoporphyrinogen oxidase inhibitors in Euphorbia heterophylla biotypes. J. Environ. Sci. Health Part B, v. 40, n. 1, p. 101-109, 2005.

VARGAS, L. et al. Resistência de plantas daninhas a herbicidas. Viçosa, MG: JARD Production, 1999. 131 p.

VARGAS, L. Resistência de Euphorbia heterophylla L. aos herbicidas inibidores da enzima acetolactato sintase (ALS/AHAS) 2000. 69 f. Tese (Doutorado em Fitotecnia) Universidade Federal de Viçosa, Viçosa, 2000.

VARGAS, L.; ROMAN, E. S. Resistência de plantas daninhas a herbicidas: conceitos, origem e evolução. Passo Fundo: Embrapa Trigo, 2006. 22 p. html. (Embrapa Trigo. Documentos Online, 58). Disponível em: <http:// www.cnpt.embrapa.br/biblio/do/p_do58.htm>. Acesso em: 12 nov. 2012.

VIDAL, R. A.; MEROTTO JR., A. Resistência de plantas daninhas aos herbicidas. In: VIDAL, R. A.; MEROTTO JR., A., ed. Herbicidologia. Porto Alegre: Evangraf, 2001. p. 138-148.

VIDAL, R. A. et al. Diagnóstico da resistência aos herbicidas em plantas daninhas. Planta Daninha, v. 24, n. 3, p. 597604, 2006.

WRIGHT, T. R.; PENNER, D. Corn (Zea mays) acetolactate synthase sensitivity to four classes of ALS inhibiting herbicides. Weed Sci., v. 46, n. 1, p. 8-12, 1998.

YU, Q. et al. Mutations of the ALS gene endowing resistance to ALS-inhibiting herbicides in Lolium rigidum populations. Pest Manag. Sci., v. 64, n. 12, p. 1229-1236, 2008.

ZHENG, D. et al. Cross-resistance of horseweed (Conyza canadensis) populations with three different ALS mutations. Pest Manag. Sci., v. 67, n. 12, p. 1486-1492, 2011. 